\title{
Association of Helicobacter pylori vacA genotypes and peptic ulcer in Iranian population: a systematic review and meta- analysis
}

\author{
Masoud Keikha ${ }^{1,2,3}$, Mohammad Ali-Hassanzadeh ${ }^{4}$ and Mohsen Karbalaei ${ }^{5^{*}}$ (D)
}

\begin{abstract}
Background: Helicobacter pylori is accounted as the most etiologic agent for digestive disorders, in particular, the most important of them i.e. peptic ulcer and gastric cancer. In the recent years, association of vacA genotypes and gastrointestinal disorders has attracted a lot of attention. In present study, we assessed the correlation between vacA genotypes (s1, s2, m1, $\mathrm{m} 2, \mathrm{~s} 1 \mathrm{~m} 1, \mathrm{~s} 1 \mathrm{~m} 2, \mathrm{~s} 2 \mathrm{~m} 1$ and $\mathrm{s} 2 \mathrm{~m} 2$ ) and development to peptic ulcer in Iranian population.

Methods: In our study, first, 24 original articles containing of information of 3328 patients were evaluated. Statistical analysis was done by Comprehensive Meta-Analysis version 2.0 software (Biostat, Englewood, NJ, USA). In this regards, we used from fixed-effects model for analysis of data with low heterogeneity, while for analysis of data with high heterogeneity ( $P^{2}$ statistic index $>25 \%$, Cochrane $Q$ statistic $p$ value $<0.05$ ), random-effects model was used.

Results: Abundance of each of $\mathrm{s} 1, \mathrm{~s} 2, \mathrm{~m} 1, \mathrm{~m} 2, \mathrm{~s} 1 \mathrm{~m} 1, \mathrm{~s} 1 \mathrm{~m} 2, \mathrm{~s} 2 \mathrm{~m} 1$, and $\mathrm{s} 2 \mathrm{~m} 2$ was estimated 36.24, 28.32, 42.90 29.86, $27.88,32.34,15.70$, and $25.94 \%$, respectively. According to the results, the $\mathrm{m} 1, \mathrm{~s} 1$, and $\mathrm{s} 1 \mathrm{~m} 2$ genotypes were among the most prevalent genotypes among the Iranian patients, whereas, s2m1 genotype had the lowest frequency.

Conclusions: Overall, 24 articles (total participants $=3328$ ) were included in this comprehensive analysis. H. pylori infection rate were $90.26 \%$ in these cases, so that $33.65 \%$ of whom had peptic ulcer. Moreover, the abundance of each vacA genotypes including s1, s2, m1, m2, s1 m1, s1 m2, s2m1, and s2m2 was estimated as 36.24, 28.32, 42.9029 .86 , $27.88,32.34,15.70$, and $25.94 \%$ respectively. We demonstrated that there is a significant relationship between infection of stomach with $\mathrm{m} 1, \mathrm{~s} 1 \mathrm{~m} 1$, and s $2 \mathrm{~m} 1$ genotypes and development to peptic ulcer disease.
\end{abstract}

Keywords: Helicobacter pylori, Iran, Peptic ulcer disease, vacA genotypes

\section{Background}

In the gastrointestinal tract, peptic ulcer is induced following damage to mucosa and sub-mucosa tissues, which occurs due to the imbalance between invasive factors (secretion of gastric acid, pepsin, bile salts, increase of oxygen free radicals, consumption of non-steroidal anti-

\footnotetext{
* Correspondence: mohsen.karbalaei@jmu.ac.ir

${ }^{5}$ Department of Microbiology and Virology, School of Medicine, Jiroft University of Medical Sciences, Jiroft, Iran

Full list of author information is available at the end of the article
}

inflammatory drugs, and infection with $H$. pylori) and host defensive mechanisms (mucus, bicarbonate, prostaglandin, antioxidant, and blood circulation) [1-4]. While ulcers occur in gastric epithelium, is called gastric ulcer, and when lesions happen in the first part of duodenum, so called duodenal ulcer $[5,6]$. The prevalence of peptic ulcer in different areas of world has been estimated $6-15 \%$. Based on reports from The Ministry of Health and Medical Education (MOHME) of Iran, of all eight Iranians, one person has experienced peptic ulcer in his/her life,

(c) The Author(s). 2020 Open Access This article is licensed under a Creative Commons Attribution 4.0 International License, which permits use, sharing, adaptation, distribution and reproduction in any medium or format, as long as you give appropriate credit to the original author(s) and the source, provide a link to the Creative Commons licence, and indicate if changes were made. The images or other third party material in this article are included in the article's Creative Commons licence, unless indicated otherwise in a credit line to the material. If material is not included in the article's Creative Commons licence and your intended use is not permitted by statutory regulation or exceeds the permitted use, you will need to obtain permission directly from the copyright holder. To view a copy of this licence, visit http://creativecommons.org/licenses/by/4.0/. The Creative Commons Public Domain Dedication waiver (http://creativecommons.org/publicdomain/zero/1.0/) applies to the data made available in this article, unless otherwise stated in a credit line to the data. 
however, the frequency of duodenal ulcer is more than gastric ulcer [7-9]. According to review of the literature, infection with both $H$. pylori and non-steroidal antiinflammatory drugs (NSAIDs) are considered as the most important causing agents for peptic ulcers, but the role of H. pylori is more prominent, so that this bacterium has isolated from 60 to $80 \%$ of peptic ulcer cases [9-11]. $H$. pylori and NSAIDs by independent mechanisms, but synergistically lead to severe inflammation and consequently peptic ulcer [12, 13]. H. pylori is a microaerophilic, S shaped, gram negative, and motile (by lophotrichous flagella) bacterium which is able to be colonized in human stomach [14]. Almost half of world population are infected to H. pylori, nevertheless, the rate of colonization in developing countries is more compared to western countries; most of population in developing countries first time infected with this bacterium in childhood ages [14, 15]. The International Agency for Research on Cancer (IARC) introduced this bacterium as the main causing enemy of gastric cancer [16, 17]. Also, this bacterium is accounted for some diseases such as primary gastric non-Hodgkin's lymphoma, mucosa-associated lymphoid tissue lymphoma (MALT), gastritis, and peptic ulcer [18]. In recent years, virulence factors of $\mathrm{H}$. pylori, and above all, cytotoxinassociated gene A (CagA) and vacuolating cytotoxin A $(V a c A)$ have more considered. VacA antigen is one of the well-known virulence factors of this pathogen which its gene, $v a c A$, is present in all strains. The mosaic-like structure of $v a c A$ gene has both conserved and variable allelic sequences. These variable sequences are found in different regions from $\mathrm{N}$-terminal side including signal sequence (s1 and s2) region, intermediate (i1 and i2) region, deletion ( $\mathrm{d} 1$ and $\mathrm{d} 2$ ) region, and mid ( $\mathrm{m} 1$ and $\mathrm{m} 2$ ) region, respectively. Whilst the cytotoxicity power of all genotypes differs from each other, in addition, two $\mathrm{s} 1$ and $\mathrm{m} 1$ regions in turn comprise several subtypes including s1a, s1b, s1c, $\mathrm{m} 1 \mathrm{a}, \mathrm{m} 1 \mathrm{~b}$ and $\mathrm{m} 1 \mathrm{c}[14,19-21]$. This antigen through induction of cytoplasmic vacuolation and apoptosis in infected cells can lead to the death of host gastric epithelial cells $[14,22]$. In addition, the toxin causes dysregulation of normal signaling pathway via happens such as alternation in the mitogen-activated protein kinases (MAPKs) pathway, polarization, suppression of proliferation and migration, as well as cytoskeletal changes [21, 22]. Evidence show that there is a significant relationship between the presence of $v a c A$ gene and progression of disease to peptic ulcer and gastric cancer [23, 24]. However, some studies have also rejected this correlation $[25,26]$. Despite about 25 years from introduction of $\mathrm{VacA}$ antigen by Cover et al., but so far its properties has no recognized correctly. In Iran the abundance of peptic ulcer is about $41 \%$ (95\% confidence interval, or 95\% CI), which is much more compared to the global average $(6-15 \%)[7,19,27]$. Some characteristics such as high colonization by $H$. pylori (about 90\%) and genetic diversity in H. pylori strains are influential in this phenomenon [28]. The main goal of this study was the determination of frequency of $v a c A(\mathrm{~s} 1, \mathrm{~s} 2$, $\mathrm{m} 1, \mathrm{~m} 2, \mathrm{~s} 1 \mathrm{~m} 1, \mathrm{~s} 1 \mathrm{~m} 2, \mathrm{~s} 2 \mathrm{~m} 1$ and $\mathrm{s} 2 \mathrm{~m} 2$ ) alleles and also their relationship with creation of peptic ulcer in Iranian population.

\section{Methods \\ Search strategy}

In the beginning, all studies (English and Persian) were received until March 2020 from global databases such as Google scholar, Scopus, PubMed, EMBASE, and also Iranian databases of IranMedex, SID, ISC. We used from keywords based on MeSH including "Helicobacter pylori", "peptic ulcer", "genotypes", "Iran", "VacA protein", and "gastric ulcer". In final, based on our inclusion criteria eligibility of articles was evaluated by two authors, separately (Fig. 1). The inclusion criteria were included original articles (cross-sectional, case-control, and cohort studies) associated with $v a c A$ genotypes (s1, s2, m1, $\mathrm{m} 2, \mathrm{~s} 1 \mathrm{~m} 1, \mathrm{~s} 1 \mathrm{~m} 2, \mathrm{~s} 2 \mathrm{~m} 1$, and $\mathrm{s} 2 \mathrm{~m} 2$ ) in Iranian patients with peptic ulcer, and also original articles about the identification of $H$. pylori and its $v a c A$ genotypes. Whilst, other studies such as reviews, letter to editor, congress abstracts, laboratory animal's studies, case reports, studies of other countries, ambiguous studies, and non-clinical studies were excluded from our research.

\section{Quality assessment and data extraction}

Quality assessment of eligible studies was done based on the checklist. Afterwards, the most important information such as first author, publication year, city, age and gender distribution, number of $H$. pylori strains, number of peptic ulcer patients, and frequency of vacA genotypes (s1, s2, m1, m2, s1m1, s1m2, s2m1, and $\mathrm{s} 2 \mathrm{~m} 2$ ) was reported for each study (Table 1).

\section{Data analysis}

In the present meta-analysis, we estimated abundance of each $v a c A$ genotypes in Iranian patients with peptic ulcer. Possible relationship between each vacA genotypes and development of peptic ulcer was measured by Odds Ratio (OR) with 95\% CIs [18]. Statistical analysis was done by Comprehensive Meta-Analysis version 2.0 software (Biostat, Englewood, NJ, USA). In this regards, we used from fixed-effects model for analysis of data with low heterogeneity, while for analysis of data with high heterogeneity $\left(I^{2}\right.$ statistic index $>25 \%$, Cochrane $Q$ statistic $p$ value $<0.05$ ), random-effects model was used. On the other hand, for estimation of publication bias, the Egger's regression model was employed. 


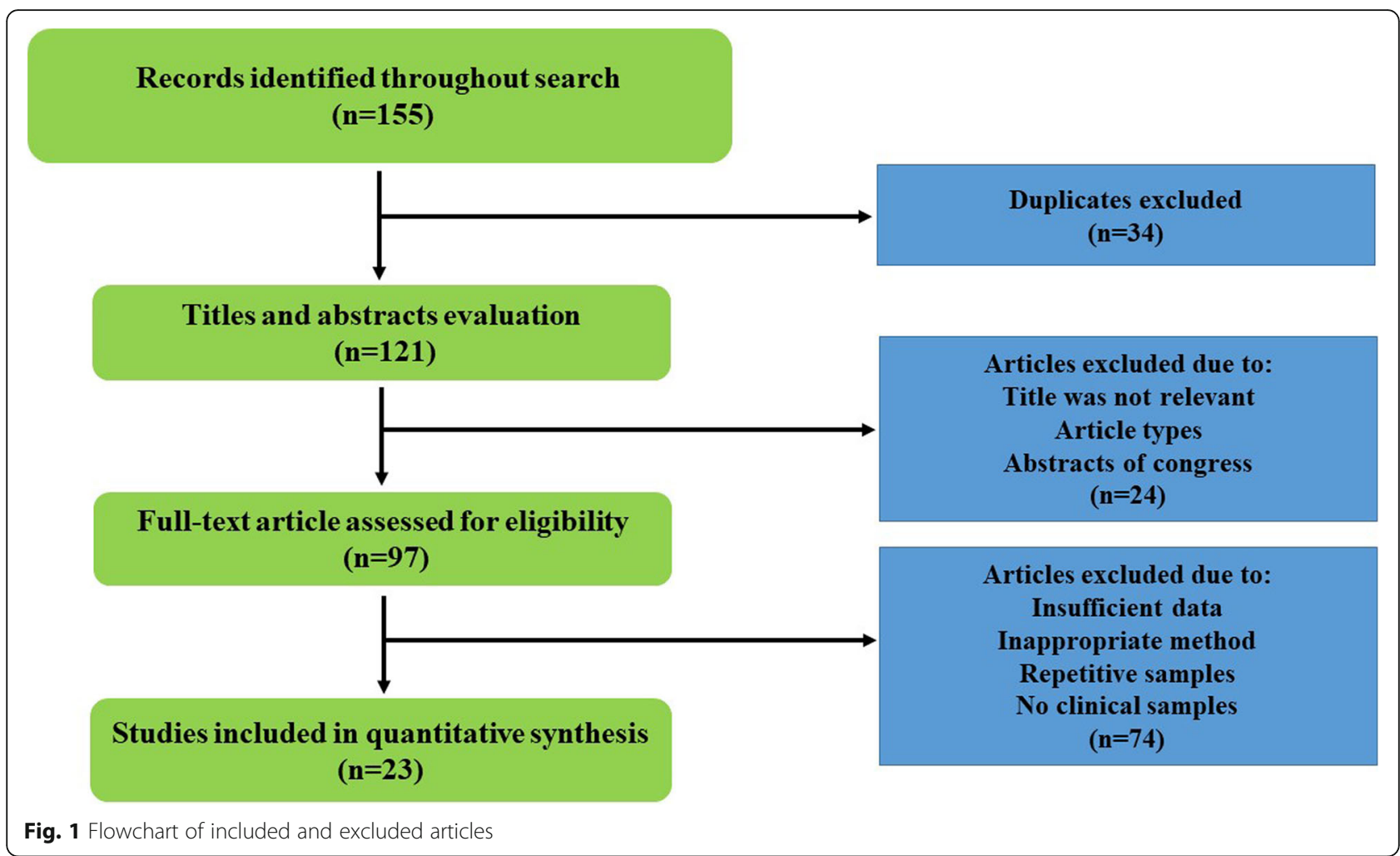

\section{Results}

Following initial searches, 155 articles was received from various databases. Finally, after study of titles, abstracts, and conformity with eligible criteria, 24 articles met inclusion criteria and were analyzed in present study [2952]. Studies were done during 2003-2019, and from Tehran (43.4\%), Tabriz (13\%), Shiraz and Jahrom (8.6\%), and Shahrekord, Kerman, Kermanshah, Rasht, Isfahan, and Hamadan (each, one study) cities (Table 1).

In the present meta-analysis, information of 3328 patients was evaluated which of them, about $55.05 \%$ were men, and about $44.95 \%$ of them were women; average age of studied population was about $41.1 \pm 2$. Among all cultured samples, H. pylori was isolated from 3004 (90.26\%) cultivated biopsies, and also 1120 (33.65\%) cases had peptic ulcer. The result of cultured samples of other patients (324 cases) with peptic ulcer was negative. Peptic ulcer in patients with negative culture could be due to administration of nonsteroidal anti-inflammatory drugs (NSAIDs), and or non-growth of this fastidious bacterium on the culture media. In addition, among of patients with peptic ulcers, frequency of duodenal ulcer cases was more than gastric ulcer ones. Abundance of each of s1, s2, m1, m2, s1m1, s1m2, s2m1, and $\mathrm{s} 2 \mathrm{~m} 2$ was estimated 36.24, 28.32, 42.90 29.86, 27.88, 32.34, 15.70 , and $25.94 \%$, respectively. Regarding this, it was demonstrated that $v a c A$ genotypes such as $\mathrm{m} 1$, s1, and s1m2 were the most prevalent $v a c A$ alleles among the
Iranian patients with peptic ulcer. Finally, based on statistical analysis estimations, a significant relationship was observed between infections by $\mathrm{m} 1, \mathrm{~s} 1 \mathrm{~m} 1$, and $\mathrm{s} 2 \mathrm{~m} 1$ alleles and development to peptic ulcer (OR 1.36, 1.24 and 4.82 respectively) in Iranian patients (Figs. 2, 3, and 4).

The pooled ORs and 95\% CIs for relationship between each of $v a c A$ genotypes and susceptibility to peptic ulcer in the Iranian population is summarized in Table 2. Furthermore, the frequency of coexistence of $v a c A$ and $\operatorname{cag} A$ genotypes in patients with peptic ulcer was evaluated about $33.35 \%$. We found a meaningful relationship between infection with $v a c A$ and $\operatorname{cagA}$ positive strains of $H$. pylori and development to peptic ulcer (OR: 1.63, 1.39-1.91; Q-value: $12.15 ; I^{2}: 0.00 ; p$ value: 0.00 and Egger's regression: 0.53) (Fig. 5). In addition, frequency of $\operatorname{cag} A$ gene in $\mathrm{s} 1, \mathrm{~s} 2, \mathrm{~m} 1, \mathrm{~m} 2, \mathrm{~s} 1 \mathrm{~m} 1, \mathrm{~s} 1 \mathrm{~m} 2, \mathrm{~s} 2 \mathrm{~m} 1$ and $\mathrm{s} 2 \mathrm{~m} 2$ genotypes was estimated $46.08,11.14,12.34,35.24$, $20.18,50,6.62$, and $15.96 \%$, respectively. Thus, s1m2, s1, and $\mathrm{m} 2$ genotypes were the most prevalent genotypes which harboring $\operatorname{cag} A$ gene, respectively. However, due to limited information, we could not evaluate the frequency of cagA gene in each of $v a c A$ genotypes isolated from Iranian patients with peptic ulcer.

\section{Discussion}

In the present study, we estimated the frequency of peptic ulcer about $33 \%$ in Iranian patients infected with $H$. pylori, which despite of higher prevalence than global 
Table 1 Characteristics of included studies

\begin{tabular}{|c|c|c|c|c|c|c|c|c|c|c|c|c|c|c|c|}
\hline \multirow[t]{2}{*}{ First Author } & \multirow[t]{2}{*}{ Year } & \multirow[t]{2}{*}{ City } & \multirow{2}{*}{$\begin{array}{l}\text { Peptic } \\
\text { ulcer }\end{array}$} & \multirow{2}{*}{$\begin{array}{l}\text { H. } \\
\text { pylori } \\
\text { isolates }\end{array}$} & \multirow{2}{*}{$\begin{array}{l}\text { Age } \\
\text { Female/Male }\end{array}$} & \multirow[t]{2}{*}{$\operatorname{cag} A$} & \multicolumn{8}{|c|}{ VacA genotypes } & \multirow[t]{2}{*}{ Ref } \\
\hline & & & & & & & s1 & s2 & $\mathrm{m} 1$ & $\mathrm{~m} 2$ & s1m1 & $\mathrm{s} 1 \mathrm{~m} 2$ & $\mathrm{~s} 2 \mathrm{~m} 1$ & $\mathrm{~s} 2 \mathrm{~m} 2$ & \\
\hline Dabiri & 2017 & Tehran & 40 & 160 & $\begin{array}{l}45.5 \pm 1 \\
81 / 79\end{array}$ & 26 & $24 / 109$ & $16 / 51$ & $12 / 48$ & $28 / 112$ & $4 / 30$ & $20 / 79$ & $8 / 18$ & $8 / 33$ & {$[29]$} \\
\hline Salari & 2009 & Tehran & 50 & 50 & $\begin{array}{l}45 \\
21 / 29\end{array}$ & NA & $50 / 50$ & $0 / 0$ & $31 / 31$ & 19/19 & NA & NA & NA & NA & {$[30]$} \\
\hline Salehi & 2011 & Tehran & 54 & 100 & $\begin{array}{l}9 \\
53 / 70\end{array}$ & NA & $42 / 62$ & $7 / 19$ & $34 / 36$ & $15 / 45$ & NA & NA & NA & NA & {$[31]$} \\
\hline Doosti & 2009 & Shahrekord & 150 & 178 & $\begin{array}{l}\text { NA } \\
\text { NA }\end{array}$ & NA & NA & NA & NA & NA & $24 / 38$ & $56 / 96$ & $0 / 7$ & $3 / 39$ & {$[32]$} \\
\hline Nahaei & 2008 & Tabriz & 48 & 150 & $\begin{array}{l}38.3 \\
74 / 76\end{array}$ & 31 & $20 / 83$ & $3 / 36$ & $8 / 43$ & $15 / 76$ & $7 / 36$ & $13 / 47$ & $1 / 7$ & $2 / 29$ & [33] \\
\hline Douraghi & 2010 & Tehran & 12 & 80 & $\begin{array}{l}43.3 \pm 1 \\
56 / 60\end{array}$ & NA & $7 / 61$ & $N A / 19$ & $3 / 26$ & $9 / 54$ & $8 / 26$ & $12 / 35$ & 0 & $8 / 19$ & {$[34]$} \\
\hline Alikhani & 2014 & Hamadan & 27 & 137 & $\begin{array}{l}53 \\
64 / 89\end{array}$ & 25 & $16 / 52$ & $5 / 16$ & $8 / 21$ & $13 / 47$ & $6 / 16$ & $10 / 36$ & $2 / 5$ & $3 / 11$ & {$[35]$} \\
\hline Sarvestani & 2007 & Shiraz & 33 & 69 & $\begin{array}{l}47.2 \\
127 / 137\end{array}$ & 37 & NA & NA & NA & NA & $1 / 65$ & $6 / 97$ & $0 / 65$ & NA & {$[36]$} \\
\hline Salehi & 2009 & Rasht & 77 & 106 & $\begin{array}{l}41 \\
46 / 38\end{array}$ & 44 & $39 / 55$ & $9 / 22$ & $31 / 31$ & $18 / 29$ & NA & NA & NA & NA & {$[37]$} \\
\hline Abdollahi & 2019 & Kerman & 6 & 120 & $\begin{array}{l}38.2 \\
98 / 93\end{array}$ & 4 & $6 / 45$ & NA & $2 / 29$ & $3 / 29$ & NA & NA & NA & NA & {$[38]$} \\
\hline Havaei & 2014 & Isfahan & 40 & 100 & $\begin{array}{l}43 \\
45 / 55\end{array}$ & NA & $40 / 100$ & NA & $21 / 51$ & $19 / 49$ & $21 / 51$ & $19 / 49$ & NA & NA & [39] \\
\hline Ghotaslou & 2013 & Tabriz & 62 & 115 & $\begin{array}{l}\text { NA } \\
\text { NA }\end{array}$ & 47 & $48 / 82$ & $47 / 79$ & $14 / 21$ & $48 / 94$ & $13 / 19$ & $35 / 63$ & $1 / 2$ & $47 / 79$ & {$[40]$} \\
\hline Khodaii & 2010 & Tehran & 73 & 141 & $41.4 \pm 699 / 58$ & 56 & $57 / 97$ & $16 / 43$ & $32 / 47$ & $41 / 93$ & $16 / 29$ & $37 / 64$ & $6 / 14$ & $14 / 33$ & [41] \\
\hline Dabiri & 2009 & Tehran & 13 & 124 & $\begin{array}{l}44.3 \\
65 / 59\end{array}$ & 6 & $8 / 50$ & $5 / 24$ & $6 / 22$ & $7 / 52$ & $2 / 15$ & $6 / 35$ & $4 / 7$ & $1 / 17$ & {$[42]$} \\
\hline Khodaii & 2013 & Tehran & 83 & 157 & $\begin{array}{l}41.1 \\
58 / 99\end{array}$ & 56 & $57 / 97$ & $16 / 43$ & $32 / 47$ & $41 / 93$ & $16 / 29$ & $37 / 64$ & $6 / 14$ & $14 / 33$ & [43] \\
\hline Rezaeian & 2012 & Jahrom & 38 & 164 & $\begin{array}{l}47 \\
58 / 79\end{array}$ & 34 & NA & NA & NA & NA & $18 / 63$ & $12 / 73$ & $1 / 6$ & $7 / 22$ & {$[44]$} \\
\hline Sedaghat & 2014 & Kashan & 8 & 37 & $\begin{array}{l}44.6 \pm 1 \\
123 / 99\end{array}$ & 4 & $4 / 20$ & $3 / 13$ & $1 / 9$ & $6 / 23$ & $0 / 6$ & $4 / 15$ & $1 / 2$ & $2 / 8$ & {$[45]$} \\
\hline Rafeey & 2013 & Tabriz & 4 & 33 & $\begin{array}{l}8.28 \\
\text { NA }\end{array}$ & 2 & $1 / 37$ & $1 / 20$ & $0 / 16$ & $2 / 41$ & NA & NA & NA & NA & {$[46]$} \\
\hline Souod & 2013 & Jahrom & 38 & 201 & $\begin{array}{l}47 \pm 1 \\
85 / 79\end{array}$ & 34 & $15 / 135$ & $8 / 29$ & 19/67 & 19/97 & 23/108 & $10 / 73$ & $1 / 6$ & $7 / 22$ & {$[47]$} \\
\hline Pajavand & 2015 & Kermanshah & 20 & 96 & $\begin{array}{l}46 \\
41 / 55\end{array}$ & NA & $19 / 47$ & $1 / 49$ & $3 / 10$ & $17 / 86$ & NA & $16 / 38$ & NA & $1 / 47$ & {$[48]$} \\
\hline Jafari & 2008 & Tehran & 19 & 96 & $\begin{array}{l}48 \pm 1 \\
29 / 26\end{array}$ & 15 & $10 / 66$ & $8 / 27$ & $4 / 30$ & $13 / 59$ & $2 / 22$ & $7 / 40$ & $2 / 8$ & $6 / 19$ & [49] \\
\hline Mohammadi & 2003 & Tehran & 29 & 132 & $\begin{array}{l}37.6 \\
65 / 67\end{array}$ & NA & $23 / 93$ & $4 / 36$ & $8 / 42$ & $17 / 74$ & $6 / 35$ & $14 / 43$ & $0 / 4$ & $3 / 31$ & {$[50]$} \\
\hline Falsafi & 2015 & Tehran & 34 & 172 & $\begin{array}{l}9.5 \pm 2 \\
72 / 37\end{array}$ & NA & NA & NA & NA & NA & $8 / 34$ & $14 / 59$ & $5 / 26$ & $7 / 40$ & [51] \\
\hline Sarvestani & 2006 & Shiraz & 61 & 286 & $45.3 \pm 1136 / 150$ & 54 & NA & NA & NA & NA & $21 / 81$ & $33 / 110$ & NA & $11 / 73$ & [52] \\
\hline
\end{tabular}

average, but confirms previous studies from Iran. Perhaps this phenomenon is to be due to some factors such as genetic properties of Iranian population, life style, and characteristics of circulating strains in Iran [7, 53]. Among the patient possessed peptic ulcer, frequency of duodenal ulcer was more than gastric ulcer, and also, the majority of patients were male. Further, like previous studies, age average of studied cases was measured about 41 years old $[12,26]$. Regarding the present results, $v a c A$ genotypes $\mathrm{m} 1, \mathrm{~s} 1$, and $\mathrm{s} 1 \mathrm{~m} 2$ were the three most 


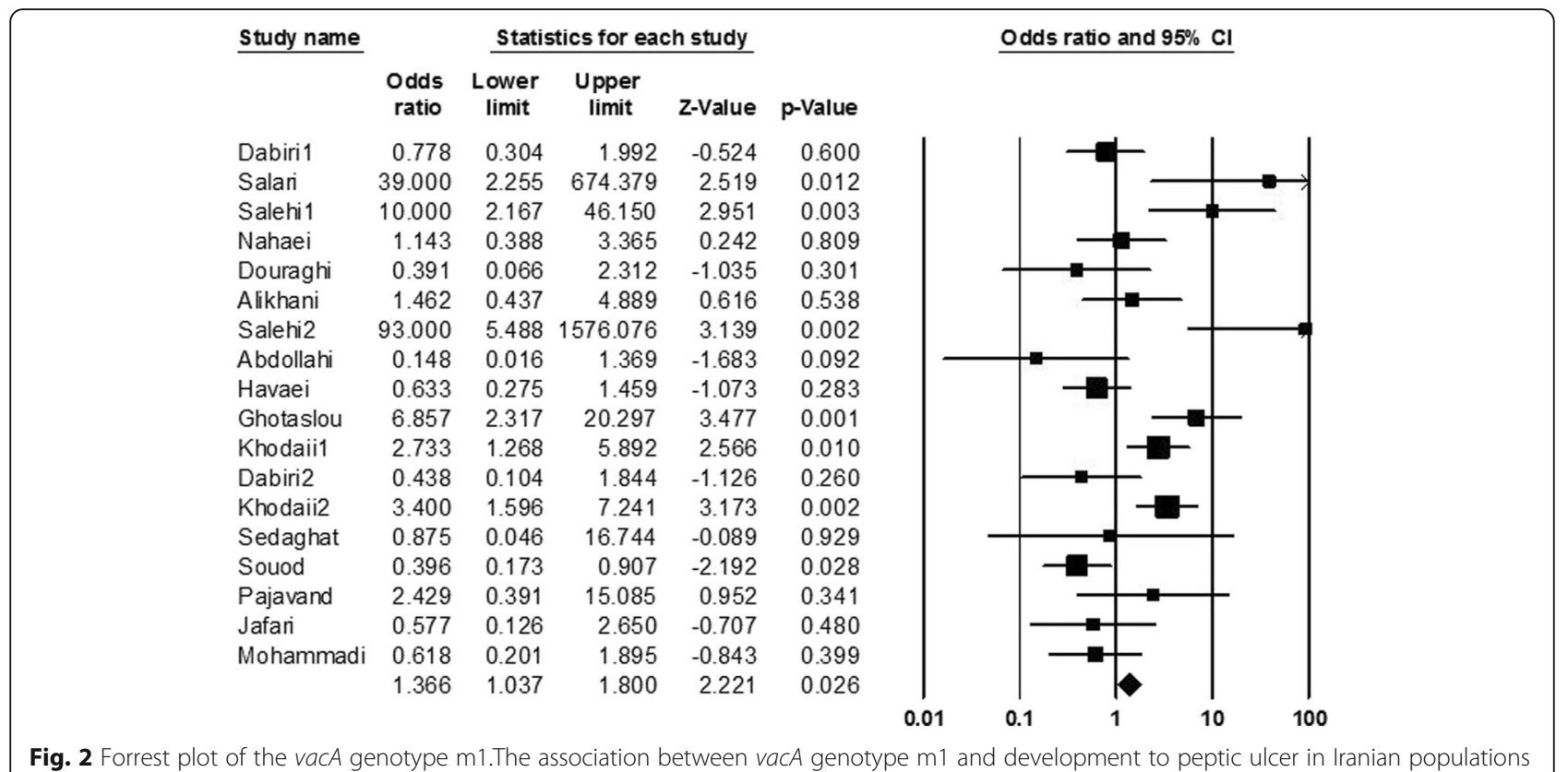

Fig. 2 Forrest plot of the vacA genotype m1.The association between vacA genotype $\mathrm{m} 1$ and development to peptic ulcer in Iranian populations

\begin{tabular}{|c|c|c|c|c|c|c|c|c|}
\hline \multirow[t]{2}{*}{ Study name } & \multicolumn{5}{|c|}{ Statis tics for each study } & \multicolumn{3}{|c|}{ Odds ratio and $95 \% \mathrm{CI}$} \\
\hline & $\begin{array}{l}\text { Odds } \\
\text { ratio }\end{array}$ & $\begin{array}{c}\text { Lower } \\
\text { limit }\end{array}$ & $\begin{array}{c}\text { Upper } \\
\text { limit }\end{array}$ & Z-Value & p-Value & & & \\
\hline Dabiri1 & 1.769 & 0.408 & 7.671 & 0.762 & 0.446 & & & \\
\hline Salari & 47.000 & 2.734 & 807.942 & 2.653 & 0.008 & & & \\
\hline Doosti & 1.714 & 0.719 & 4.086 & 1216 & 0.224 & & & \\
\hline Nahaei & 0.172 & 0.042 & 0.709 & -2.437 & 0.015 & & & \\
\hline Douraghi & 1.056 & 0.327 & 3.411 & 0.090 & 0.928 & & & \\
\hline Alikhani & 2.700 & 0.704 & 10.355 & 1.448 & 0.148 & & & \\
\hline Sarvestani1 & 1.188 & 0.073 & 19.366 & 0.121 & 0.904 & & & \\
\hline Havaei & 1.367 & 0.635 & 2.942 & 0.799 & 0.424 & & & \\
\hline Ghotaslou & 10.000 & 3.204 & 31.208 & 3.965 & 0.000 & & & \\
\hline Khodaii1 & 0.045 & 0.002 & 0.833 & -2.083 & 0.037 & & & \\
\hline Dabiri2 & 6.231 & 0.806 & 48.186 & 1.753 & 0.080 & & & \\
\hline Khodaii2 & 1.692 & 0.638 & 4.486 & 1.058 & 0.290 & & & \\
\hline Rezaeian & 0.024 & 0.001 & 0.436 & -2.521 & 0.012 & & & \\
\hline Rafeey & 11.333 & 1.835 & 69.982 & 2.614 & 0.009 & & & \\
\hline Pajavand & 1.000 & 0.268 & 3.737 & 0.000 & 1.000 & & & \\
\hline Jafari & 1.350 & 0.175 & 10.419 & 0.288 & 0.773 & & & \\
\hline Mohammadi & 0.933 & 0.359 & 2.429 & -0.141 & 0.888 & & & \\
\hline Falsafi & 1.000 & 0.326 & 3.067 & 0.000 & 1.000 & & & \\
\hline \multirow[t]{3}{*}{ Sarvestani2 } & 0.667 & 0.323 & 1.377 & -1.096 & 0.273 & & & \\
\hline & 1.331 & 1.005 & 1.761 & 1.998 & 0.046 & & & \\
\hline & & & & & & 0.01 & 0.1 & 100 \\
\hline
\end{tabular}




\begin{tabular}{|c|c|c|c|c|c|c|c|c|c|}
\hline \multirow[t]{2}{*}{ Study name } & \multicolumn{5}{|c|}{ Statistics for each study } & \multicolumn{4}{|c|}{ Odds ratio and $95 \% \mathrm{Cl}$} \\
\hline & $\begin{array}{l}\text { Odds } \\
\text { ratio }\end{array}$ & $\begin{array}{c}\text { Lower } \\
\text { limit }\end{array}$ & $\begin{array}{c}\text { Upper } \\
\text { limit }\end{array}$ & Z-Value & p-Value & & & & \\
\hline Dabiri1 & 3.200 & 0.954 & 10.733 & 1.884 & 0.060 & & & & \\
\hline Nahaei & 7.833 & 0.431 & 142.239 & 1.392 & 0.164 & & & & \\
\hline Alikhani & 8.333 & 0.838 & 82.858 & 1.809 & 0.070 & & & & \\
\hline Ghotaslou & 61.000 & 2.028 & 1835.172 & 2.367 & 0.018 & & & & \\
\hline Khodaii1 & 8.375 & 2.175 & 32.252 & 3.089 & 0.002 & & & & \\
\hline Dabini2 & 3.000 & 0.447 & 20.153 & 1.130 & 0.258 & & & & \\
\hline Khodaii2 & 9.625 & 2.506 & 36.964 & 3.298 & 0.001 & & & & \\
\hline Rezaeian & 7.400 & 0.397 & 137.879 & 1.341 & 0.180 & & & & \\
\hline Sedaghat & 7.000 & 0.217 & 226.005 & 1.098 & 0.272 & & & & \\
\hline Souod & 7.400 & 0.397 & 137.879 & 1.341 & 0.180 & & & & \\
\hline Jafari & 2.833 & 0.324 & 24.808 & 0.941 & 0.347 & & & & \\
\hline \multirow[t]{3}{*}{ Falsafi } & 1.381 & 0.354 & 5.385 & 0.465 & 0.642 & & & & \\
\hline & 4.819 & 2.829 & 8.209 & 5.787 & 0.000 & & & & \\
\hline & & & & & & 0.01 & 0.1 & 10 & 100 \\
\hline
\end{tabular}

prevalent isolated genotypes from Iranian patients involved with peptic ulcer. As well as, we demonstrated that there is a significant relationship between infection by strains containing $\mathrm{m} 1, \mathrm{~s} 1 \mathrm{~m} 1$, and $\mathrm{s} 2 \mathrm{~m} 1$ genotypes and progression to peptic ulcer. Besides, in this metaanalysis, frequency of strains containing coexistence of $v a c A$ and $\operatorname{cag} A$ genes in peptic ulcer patients was assessed about $33.35 \%$. We showed that there is a meaningful relationship between infections by $\operatorname{cagA} / v a c A$ positive strains and development to peptic ulcer. $H$. pylori possesses some unique characteristics which cause to persist of bacterial infection in acidic condition of stomach and also evading from immune system [53, 54]. The colonization by this bacterium is different in various

Table 2 Summary of OR with 95\% Cls for comparison of all vacA genotypes with each other

\begin{tabular}{|c|c|c|c|c|c|}
\hline \multirow{2}{*}{$\begin{array}{l}\text { vacA } \\
\text { genotypes }\end{array}$} & \multicolumn{2}{|l|}{ Odds Ratio } & \multicolumn{2}{|c|}{ Heterogeneity } & \multirow{2}{*}{$\begin{array}{l}\text { Egger's } \\
\text { regression }\end{array}$} \\
\hline & $95 \% \mathrm{Cls}$ & $p$ value & Q-value & $\overline{R^{2} \text {-squared }}$ & \\
\hline s1 & $0.35 ; 0.28-0.44$ & 0.00 & 69.13 & 75.40 & 0.12 \\
\hline s2 & $1.21 ; 0.86-1.62$ & 0.20 & 30.42 & 53.98 & 0.23 \\
\hline m1 & $1.36 ; 1.03-1.80$ & 0.026 & 62.68 & 72.88 & 0.02 \\
\hline $\mathrm{m} 2$ & $0.42 ; 0.34-0.53$ & 0.00 & 97.55 & 81.54 & 0.05 \\
\hline $\mathrm{s} 1 \mathrm{~m} 1$ & $1.33 ; 1.00-1.76$ & 0.046 & 52.54 & 65.74 & 0.46 \\
\hline $\mathrm{s} 1 \mathrm{~m} 2$ & $0.73 ; 0.60-0.90$ & 0.003 & 58.24 & 69.09 & 0.02 \\
\hline$s 2 \mathrm{~m} 1$ & $4.81 ; 2.82-8.20$ & 0.00 & 8.48 & 0.00 & 0.53 \\
\hline $\mathrm{s} 2 \mathrm{~m} 2$ & $1.28 ; 0.94-1.72$ & 0.10 & 25.40 & 37.02 & 0.03 \\
\hline
\end{tabular}

regions worldwide; for example, in Iran, $90 \%$ of population are infected with $H$. pylori [55]. Nevertheless, most of infected people remain as an asymptomatic carrier throughout the life of themselves; peptic ulcer and gastric cancer happen in $10-15$ and $2 \%$ of infected cases, respectively $[53,55]$. It seems that the infection by $H$. pylori can be related to socioeconomic status which in turn effects on papulation's lifestyle. The outcomes of clinical manifestations of this bacterium are influenced by three factors, severity of strains, host genetics, and environment [56]. Reciprocally and over the time the stomach status such as acidity, buffering and mucus content can be affected by lifestyle factors such as diet, food habits, alcoholism, oral hygiene, water hygiene, personal hygiene, and so on [57]. In this regard, low socioeconomic status, overcrowding, poor hygiene, as well as living in the developing countries are considered as risk factors for progressing of primary infection to more severe complications including chronic gastritis, peptic ulcer, and also gastric cancer [58]. Overall, the prevalence of infections by this bacterium in developing countries, in particular in the countries with low socioeconomic status and poor health management (> $80 \%)$ is much higher than the developed ones $(<40 \%)$, [59]. Based on Safak et al., the prevalence of cagA- and vacAs1-positive strains in patients with active chronic gastritis was more than non-active chronic gastritis ( $45.8 \%$ vs 21.6 and $78.0 \%$ vs $40.5 \%$, respectively) [60]. On the other hand, it seems that host genetic properties and pathogenicity power of $H$. pylori strains are as two 


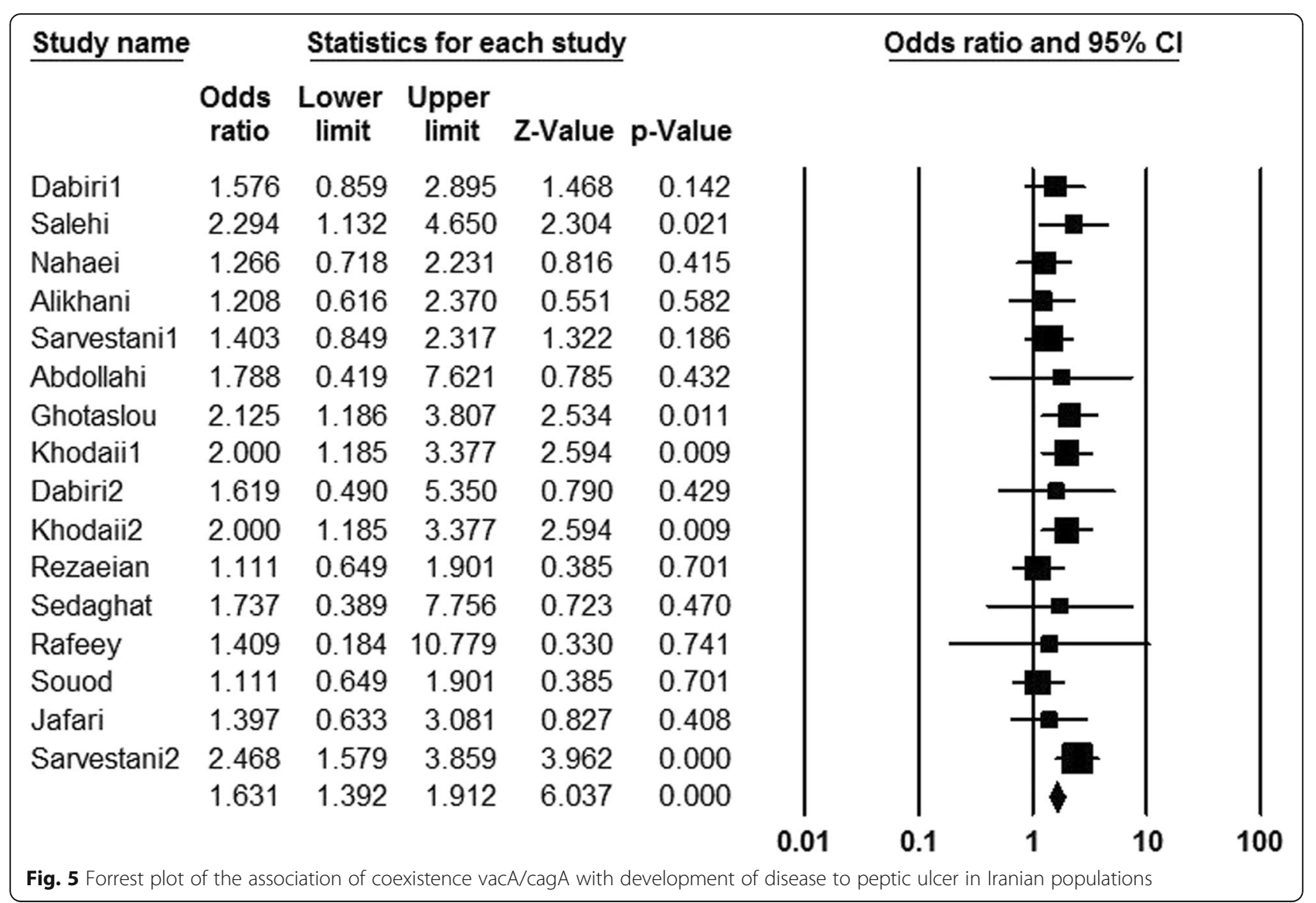

determining factors in the onset of disease and final outcomes [53, 61]. According to review of the literature, global prevalence of peptic ulcer has been estimated about $10 \%$, and this bacterium isolated from 90 to $100 \%$ and $60-90 \%$ cases of duodenal ulcer and gastric ulcer, respectively [53]. Nonetheless, frequency of peptic ulcer in Iran is much more than world average, which is related to host genetic characteristics and virulence factors of bacterium $[7,53]$. Both surface antigens and cytotoxic enzymes such as $\operatorname{VacA}$ and $\operatorname{CagA}$ are accounted as the two main virulence factors of $H$. pylori [14, 24]. Based on previous meta-analysis, some virulence factors of $H$. pylori e.g. OipA, BabA, DupA, IceA, CagA, and VacA are related to progress to peptic ulcer disease $[24,53,62-$ 68]. Also, it seems that type of colonization can be effective in formation of peptic ulcer; in general, duodenal ulcer is create following antral colonization, but gastric ulcer is the result of corporal and pan-gastritis [53, 61, $68,69]$. Although $v a c A$ gene is present in all $H$. pylori strains, but its functional protein, $V a c A$ toxin, expressed in only $50 \%$ of those. The $V a c A$ protein forms a channel in membrane of bacterium, which be able to uptake of different ions and metabolites to the inside the cytoplasm, and causes to survival of bacterium in stomach mucosal layer. Endocytosis of VacA into the host cell leads to some events such as vacuoles formation, releasing cytochrome c from mitochondria, and apoptosis. In addition, VacA toxin by impressing on different receptors leads to alteration in signaling pathways of MAPK/ p38 and extracellular signal-regulated kinases 1 and 2 (ERK1/2) [19, 69-72]. Functional weight of $\mathrm{VacA}$ toxin is about $88 \mathrm{kDa}$, and forms two subunits p33 and p55. The p33 domain which contains residues $1-33$ in $\mathrm{N}$ terminal region (as signal sequence) of $\mathrm{VacA}$ toxin, and creates vacuole in host cell $[70,73]$. On the other, p55 domain acts as binding domain of toxin to the cell surface [70]. The length of $v a c A$ gene is $3860-3940 \mathrm{bp}$, and contains both conserved and variable regions. Nowadays, it has been cleared that the variable regions can be effective in variations of $v a c A$ gene expression, and directly are related to clinical outcomes of infection by $H$. pylori [70, 73]. For example, McClain et al. in 2001 showed that the hydrophobic amino acids near the cleavage site of s2, could integrated the $V a c A$ toxin with host cell membrane [74]. According to literature, vacA gene possesses variable sequences in $\mathrm{s}(\mathrm{s} 1$ and $\mathrm{s} 2)$ and $\mathrm{m}$ ( $\mathrm{m} 1$ and $\mathrm{m} 2$ ) regions. It is notable that $v a c A \mathrm{~s} 1 \mathrm{~m} 1$ has the most expression rate, and therefore high vacuolating, but $v a c A \mathrm{~s} 1 \mathrm{~m} 2$ is a moderate vacuolating genotype, as well as $v a c A \mathrm{~s} 2 \mathrm{~m} 2$ is not toxic, and finally, $v a c A \mathrm{~s} 2 \mathrm{~m} 1$ 
genotype is rare and non-toxic [75-78]. Recently, two additional variable regions, $\mathrm{i} 1 / \mathrm{i} 2$ and $\mathrm{d} 1 / \mathrm{d} 2$, have recognized in $\mathrm{m}$ region, and also, each of $\mathrm{s} 1$ and $\mathrm{m} 1$ regions subdivided to different types such s1a, s1b, s1c, m1a, $\mathrm{m} 1 \mathrm{~b}$ and $\mathrm{m} 1 \mathrm{c}[79,80]$. In the recent present, we showed that there is a significant relationship between infection by cagA positive $H$. pylori strains and peptic ulcer disease. Given that studies in this field, expression of $\operatorname{cag} A$ gene leads to increase of pathogenicity, and directly related to severity of diseases of bacterium [53]. Our study confirmed previous studies [65, 81]. Moreover, we demonstrated that $\mathrm{m} 1, \mathrm{~s} 1 \mathrm{~m} 1$, and $\mathrm{s} 2 \mathrm{~m} 1$ genotypes have direct correlation with peptic ulcer in Iranian population. But, due to limit information about the both $\mathrm{d}$ and $\mathrm{i}$ genotypes, we could not assess the effect of these genotypes on development of infection to peptic ulcer. In 2014, Basiri et al. showed that the infection by d 1 genotype of $v a c A$ gene raises the risk of primary infection towards gastric adenocarcinoma and peptic ulcer in Northwestern of Iran [82]. In another study in 2014, Mottaghi et al. studied on correlation between infection by i1 allele and development of infection into the gastric cancer and peptic ulcer in Azerbaijan, Iran; they found that $v a c A$ il genotype is significantly related to gastric cancer, however in their study, they did not find a meaningful relationship between infection by $v a c A$ i1/2 alleles and peptic ulcer gastric cancer diseases [83]. According to various European studies, it has been demonstrated that there is a significant correlation between vacA genotypes of $\mathrm{s} 1$ and $\mathrm{m} 1$ with $H$. pylori-related gastrointestinal diseases $[75,80,84-87]$. It is notable that due to decrease or absence of vacuolating activity, s2 and $\mathrm{m} 2$ genotypes rarely are related to peptic ulcer [80]. In our analysis, we observed a similar correlation about frequency of $\mathrm{s} 1$ and $\mathrm{m} 1$ alleles in patients involved by peptic ulcer with other studies, which is due to some properties of these bacterial strains such as increased binding capacity, vacuolating activity, and alternation in normal signaling pathway [75]. In addition, it is known that the origin of Iranian circulating strains is like to Western countries, in that, in 2010 Latifi-Navid et al. proved that the origin of Iranian strains is belonging to European H. pylori (hpEurope) strains. It seems that following migration of European to Iran, the hpEurope strains have been transferred to Iran, and this phenomenon can be effective in similarity of results of both our studies and Western countries [88]. Overall, most recent studies have confirmed an intimate relationship between infection by $\mathrm{s} 1 \mathrm{~m} 1$ strains and progression to gastrointestinal diseases $[24,80,89,90]$. In 2005, Martins et al. represented that a significant relevance between colonization by $v a c A$ genotype $\mathrm{s} 1 \mathrm{~m} 1$ and peptic ulcer in Brazilian population [79]. Likewise, several separate studies have confirmed relationship between $H$. pylori vacA s1m1 infection and peptic ulcer $[26,79,89$, 90]. Based on our results, s1, $\mathrm{m} 1$, and $\mathrm{s} 1 \mathrm{~m} 2$ were proposed as the most prevalent genotypes in peptic ulcer disease. In a study that was done by Sugimoto et al., in 2009, they demonstrated that the frequency of s1 and $\mathrm{m} 1$ genotypes in Middle-East patients is more than 50\%; they found that $\mathrm{s} 1 \mathrm{~m} 1$ and $\mathrm{s} 2 \mathrm{~m} 1$ were the most and lowest common genotypes in Middle-East regions, respectively, which in turn their results were according to our results [91]. While, based on Sugimoto et al. study, s1, $\mathrm{m} 1$, and $\mathrm{s} 1 \mathrm{~m} 1$ genotypes were related to peptic ulcer, but in our findings, $\mathrm{m} 1, \mathrm{~s} 1 \mathrm{~m} 1$, and $\mathrm{s} 2 \mathrm{~m} 1$ were accounted as risk factor for peptic ulcer. It may be due to difference in distribution of patients; we only studies on Iranian patients' samples [91]. We declared that there is a direct association between $v a c A$ s $2 \mathrm{~m} 1$ with peptic ulcer in Iranian patients; this is while, it seems that the strains which harboring $\mathrm{s} 2 \mathrm{~m} 1$ are non-toxic, or low capacity of vacuolation, and this finding was challenging [92]. Although due to limit information, we could not evaluate the presence of other virulence factors in $\mathrm{s} 2 \mathrm{~m} 1$ strains, it seems that these strains possess cagA gene or other required virulence factors for development to peptic ulcer. However, $H$. pylori strains from patients involved to peptic ulcer and gastric cancer in some regions such as Mexico, Latin America, Africa, and Western countries were harboring vacA s2m1 genotype [86, 87, 93]. In the same year, Sugimoto et al. demonstrated that abundance of vacA s $2 \mathrm{~m} 1$ in Mexican population is about $12.2 \%$ [80]. Furthermore, Zhang et al. displayed that infection by $v a c A \mathrm{~s} 2 \mathrm{~m} 1$ genotype and duodenal ulcer are significantly related with each other (OR: 2.30; 95\% CIs: $1.17-$ 4.50) [89]. Yet, it needed to more study about the effect of $v a c A \mathrm{~s} 2 \mathrm{~m} 1$ strains on creation of peptic ulcer. In summary, based on our and other meta-analysis results, the most common vacA genotypes involved in progressing to peptic ulcer disease which are listed in Table $3[23$, $66,91]$.

Table 3 The most common vacA genotypes involved in progressing to peptic ulcer

\begin{tabular}{|c|c|c|c|c|}
\hline $\begin{array}{l}\text { Most common genotypes } \\
\text { associated with peptic ulcer disease }\end{array}$ & Iran & Europe & $\begin{array}{l}\text { Southeast } \\
\text { Asia }\end{array}$ & $\begin{array}{l}\text { Middle } \\
\text { East }\end{array}$ \\
\hline s1 & + & + & + & + \\
\hline s2 & - & - & - & - \\
\hline m1 & + & + & + & + \\
\hline m2 & - & - & - & - \\
\hline s1m1 & - & - & - & - \\
\hline s1m2 & + & - & - & - \\
\hline $\mathrm{s} 2 \mathrm{~m} 1$ & - & - & - & - \\
\hline$s 2 m 2$ & - & - & - & - \\
\hline i1 & - & - & + & - \\
\hline
\end{tabular}




\section{Conclusions}

In general, in the present study we showed that there is a significant relationship between $v a c A$ genotypes $\mathrm{m} 1$, $\mathrm{s} 1 \mathrm{~m} 1$, and $\mathrm{s} 2 \mathrm{~m} 1$, and development of infections caused by $H$. pylori to peptic ulcer disease in Iranian population. In addition, based on collected information from Iran and other three regions including Europe, Southeast Asia, and Middle East, it seems that two main genotypes $\mathrm{s} 1$, and $\mathrm{m} 1$ are the most prevalent genotypes for progressing of primary infection to peptic ulcer. Finally, the limitations of our study were including: 1) limited information of patients; 2) spatial constraints, so that most of the studies were conducted in Tehran; 3) limited information of $v a c A \mathrm{~d}$ and $\mathrm{i}$ alleles; 4) limited information of $\operatorname{cag} A$ and other bacterial virulence factors; 5) publication bias in some studies.

\section{Abbreviations}

H. pylori: Helicobacter pylori; MOHME: Ministry of Health and Medical Education; NSAIDs: Non-steroidal anti-inflammatory drugs; IARC: International Agency for Research on Cancer; MALT: Mucosa-associated lymphoid tissue lymphoma; CagA: Cytotoxin-associated gene A; VacA: Vacuolating cytotoxin A; MAPKs: Mitogen-activated protein kinases

\section{Acknowledgements}

We appreciate from both Mashhad University of Medical Sciences and Jiroft University of Medical Sciences.

\section{Authors' contributions}

MK1 have contributed to design of the work and analysis of data. MA-H have contributed to design of the work. MK2 have drafted the work and substantively revised it. All authors read and approved the final manuscript.

\section{Funding}

We have not received any funding for this research.

\section{Availability of data and materials}

All data generated or analysed during this study are included in this published article and its supplementary information files.

\section{Ethics approval and consent to participate}

Not applicable (this paper was provided based on researching in global databases).

\section{Consent for publication \\ Not Applicable.}

\section{Competing interests}

There is no any conflict of interest among the all authors.

\begin{abstract}
Author details
${ }^{1}$ Antimicrobial Resistance Research Center, Mashhad University of Medical Sciences, Mashhad, Iran. ${ }^{2}$ Department of Microbiology and Virology, Faculty of Medicine, Mashhad University of Medical Sciences, Mashhad, Iran. ${ }^{3}$ Student Research Committee, Mashhad University of Medical Sciences, Mashhad, Iran. ${ }^{4}$ Department of Immunology, School of Medicine, Jiroft University of Medical Sciences, Jiroft, Iran. ${ }^{5}$ Department of Microbiology and Virology, School of Medicine, Jiroft University of Medical Sciences, Jiroft, Iran.
\end{abstract}

Received: 7 May 2020 Accepted: 29 July 2020

Published online: 14 August 2020

\section{References}

1. Chan FK, Leung W. Peptic-ulcer disease. Lancet. 2002;360(9337):933-41.
2. Keikha M, Eslami M, Yousefi B, Ghasemian A, Karbalaei M. Potential antigen candidates for subunit vaccine development against helicobacter pylori infection. J Cell Physiol. 2019;234(12):21460-70.

3. Yuan Y, Padol IT, Hunt RH. Peptic ulcer disease today. Nat Clin Pract Gastroenterol Hepatol. 2006;3(2):80-9.

4. Charpignon C, Lesgourgues B, Pariente A, Nahon S, Pelaquier A, GatineauSailliant $\mathrm{G}$, et al. Peptic ulcer disease: one in five is related to neither $\mathrm{H}$ elicobacter pylori nor aspirin/NSAID intake. Aliment Pharmacol Ther. 2013; 38(8):946-54.

5. Molloy R, Sonnenberg A. Relation between gastric cancer and previous peptic ulcer disease. Gut. 1997;40(2):247-52.

6. Karbalaei M, Khorshidi M, Sisakht-pour B, Ghazvini K, Farsiani H, Youssefi M, et al. What are the effects of IL-1ß (rs1143634), IL-17A promoter (rs2275913) and TLR4 (rs4986790) gene polymorphism on the outcomes of infection with $\mathrm{H}$. pylori within as Iranian population; A systematic review and metaanalysis. Gene Rep. 2020100735. https://doi.org/10.1016/j.genrep.2020. 100735.

7. Sayehmiri K, Tavan H. Systematic review and meta-analysis methods prevalence of peptic ulcer in IRAN. J Govaresh. 2015;20(4):250-8.

8. Sung J, Kuipers E, El-Serag H. Systematic review: the global incidence and prevalence of peptic ulcer disease. Aliment Pharmacol Ther. 2009:29(9):938-46.

9. Cullen D, Hawkey G, Greenwood D, Humphreys H, Shepherd V, Logan R, et al. Peptic ulcer bleeding in the elderly: relative roles of Helicobacter pylori and non-steroidal anti-inflammatory drugs. Gut. 1997;41(4):459-62.

10. Ford AC, Marwaha A, Sood R, Moayyedi P. Global prevalence of, and risk factors for, uninvestigated dyspepsia: a meta-analysis. Gut. 2015;64(7):1049-57.

11. Tanih N, Okeleye B, Ndip I, Clarke A, Naidoo N, Mkwetshana N, et al. Helicobacter pylori prevalence in dyspeptic patients in the eastern Cape Province-race and disease status. S Afr Med J. 2010;100(11):734-7.

12. Huang J-Q, Sridhar S, Hunt RH. Role of helicobacter pylori infection and non-steroidal anti-inflammatory drugs in peptic-ulcer disease: a metaanalysis. Lancet. 2002;359(9300):14-22.

13. Papatheodoridis GV, Sougioultzis S, Archimandritis AJ. Effects of helicobacter pylori and nonsteroidal anti-inflammatory drugs on peptic ulcer disease: a systematic review. Clin Gastroenterol Hepatol. 2006;4(2):130-42.

14. Kusters JG, Van Vliet AH, Kuipers EJ. Pathogenesis of helicobacter pylori infection. Clin Microbiol Rev. 2006;19(3):449-90.

15. Polk DB, Peek RM. Helicobacter pylori: gastric cancer and beyond. Nat Rev Cancer. 2010;10(6):403-14.

16. Yousefi B, Mohammadlou M, Abdollahi M, Salek Farrokhi A, Karbalaei M, Keikha $\mathrm{M}$, et al. Epigenetic changes in gastric cancer induction by helicobacter pylori. J Cell Physiol. 2019;234(12):21770-84.

17. Song H, Michel A, Nyrén O, Ekström AM, Pawlita M, Ye W. A CagA-independent cluster of antigens related to the risk of noncardia gastric cancer: associations between helicobacter pylori antibodies and gastric adenocarcinoma explored by multiplex serology. Int J Cancer. 2014;134(12):2942-50.

18. Youssefi M, Ghazvini K, Farsiani H, Tafaghoudi M, Keikha M. A systematic review and meta-analysis of outcomes of infection with helicobacter pylori dupA+ strains in Iranian patients. Gene Rep. 2020100650. https://doi.org/10. 1016/j.genrep.2020.100650.

19. Cover TL. The vacuolating cytotoxin of helicobacter pylori. Mol Microbiol. 1996;20(2):241-6.

20. Safaralizadeh R, Dastmalchi N, Hosseinpourfeizi M, Latifi-Navid S. Helicobacter pylori virulence factors in relation to gastrointestinal diseases in Iran. Microb Pathog. 2017;105:211-7.

21. Hosseini E, Poursina F, Van de Wiele T, Safaei HG, Adibi P. Helicobacter pylori in Iran: a systematic review on the association of genotypes and gastroduodenal diseases. J Res Med Sci. 2012;17(3):280.

22. Cover TL, Blanke SR. Helicobacter pylori VacA, a paradigm for toxin multifunctionality. Nat Rev Microbiol. 2005;3(4):320-32.

23. Matos JI, de Sousa HA, Marcos-Pinto R, Dinis-Ribeiro M. Helicobacter pylor CagA and VacA genotypes and gastric phenotype: a meta-analysis. Eur J Gastroenterol Hepatol. 2013;25(12):1431-41

24. Ghotaslou R, Leylabadlo HE, Nasiri MJ, Dabiri H, Hashemi A. Risk of gastric cancer in association with helicobacter pylori different virulence factors: a systematic review and meta-analysis. Microb Pathog. 2018;118:214-9.

25. Perng CL, Lin HJ, Facg SIC, Tseng GY. Helicobacter pylori cagA, iceA and vacA status in Taiwanese patients with peptic ulcer and gastritis. J Gastroenterol Hepatol. 2003;18(11):1244-9.

26. Karlsson A, Ryberg A, Dehnoei MN, Borch K, Monstein H-J. Association between cagA and vacA genotypes and pathogenesis in a helicobacter 
pylori infected population from South-Eastern Sweden. BMC Microbiol. 2012:12(1):1-8.

27. Talebkhan Y, Mohammadi M, Mohagheghi MA, Vaziri HR, Hosseini ME, Mohajerani $\mathrm{N}$, et al. cagA gene and protein status among Iranian helicobacter pylori strains. Dig Dis Sci. 2008:53(4):925-32.

28. Vaziri F, Peerayeh SN, Alebouyeh M, Mirzaei T, Yamaoka Y, Molaei M, et al. Diversity of helicobacter pylori genotypes in Iranian patients with different gastroduodenal disorders. World J Gastroenterol: WJG. 2013;19(34):5685.

29. Dabiri H, Jafari F, Baghaei K, Shokrzadeh L, Abdi S, Pourhoseingholi MA, et al. Prevalence of helicobacter pylori vacA, cagA, cagE, oipA, iceA, babA2 and babB genotypes in Iranian dyspeptic patients. Microb Pathog. 2017;105:226-30.

30. Salari M, Shirazi M, Hadaiti MA, Daryani NA. Frequency of helicobacter pylori vacA genotypes in Iranian patients with gastric and duodenal ulcer. J Infect Public Health. 2009;2(4):204-8.

31. Salehi Z, Akhshabi F, Talachian E. Prevalence of vacA and cagA genotypes of helicobacter pylori in Iranian children with peptic ulcer disease. WASJ. 2011;12(6):840-4.

32. Doosti A, Ghasemi-Dehkordi P. Helicobacter pylori vacA genotypes in Shahrekordian (Iran) H. pylori-positive patients. Res j Biol Sci. 2009;4(1):11-5.

33. Nahaei M, Sharifi Y, Akhi MT, Asgharzadeh M, Nahaei M, Fatahi E. Helicobacter pylori cagA and vacA genotypes and their relationships to peptic ulcer disease and non-ulcer dyspepsia. Res J Microbiol. 2008;3(5):386-94.

34. Douraghi M, SABERI KS, Shokrgozar MA, Oghalaei A, Esmaeili M, Bababeyk $\mathrm{M}$, et al. Characterization of the vacuolating cytotoxin in helicobacter pylori strains isolated from Iran. Yakhteh Med J. 2010;12(1):1-6.

35. Alikhani MY, Arebestani MR, Khorasani MS, Majlesi A, Jaefari M. Evaluation of Helicobacter pylori vacA and cagA genotypes and correlation with clinical outcome in patients with dyspepsia in hamadan province, Iran. Iran Red Crescent Med J. 2014;16(11):e19173.

36. Kamali SE, Farsiani H, Shamoon PM, Bazargani A, Bagheri LK, Taghavi A-R, et al. Association of myeloperoxidase-463 $\mathrm{G} / \mathrm{a}$ polymorphism with clinical outcome of helicobacter pylori infection in Iranian patients with gastrointestinal diseases. Iran J Immunol. 2007;4(3):155-60.

37. Salehi Z, Abadi ASH, Ismail PB, Kqueen CY, Jelodar MH, Kamalidehghan B. Evaluation of Helicobacterápylori vacA genotypes in Iranian patients with peptic ulcer disease. Dig Dis Sci. 2009;54(11):2399.

38. Abdollahi H, Hashemzadeh M, Khoshnood S, Savari M. Characterization of helicobacter pylori genotypes from Iranian patients with gastric clinical diseases: predominance of vacA s1a and cagA EPIYA-ABC genotypes. Gene Rep. 2019;16:100458.

39. Havaei SA, Mohajeri P, Khashei R, Salehi R, Tavakoli H. Prevalence of helicobacter pylori vacA different genotypes in Isfahan, Iran. Adv Biomed Res. 2014;3:48.

40. Ghotaslou R, Milani M, Akhi MT, Nahaei MR, Hasani A, Hejazi MS, et al. Diversity of helicobacter pylori cagA and vacA genes and its relationship with clinical outcomes in Azerbaijan. Iran. Adv Pharm Bull. 2013;3(1):57.

41. Khodaii Z, Ghaderian S, Najar RA, Nejati H, Panah AT. cagA and vacA status and influence of helicobacter pylori infection on serum oxidative DNA damage in Iranian patients with peptic ulcer disease. Ir J Med Sci. 2011; 180(1):155-61.

42. Dabiri H, Maleknejad P, Yamaoka Y, Feizabadi MM, Jafari F, Rezadehbashi M, et al. Distribution of helicobacter pylori cagA, cagE, oipA and vacA in different major ethnic groups in Tehran, Iran. J Gastroenterol Hepatol. 2009; 24(8):1380-6.

43. Khodaii Z, Ghaderian SMH, Tabatabaei PAS, Akbarzadeh NR. Evaluation of the prevalence of vacA and cagA in patients with peptic ulcer. Daneshvar Med. 2013;20(104):1-8.

44. Rezaeian AA, Kargar M, Souod N, Ghorbani Dalini S. Genetic Polymorphisms of CagA and VacA Genes in Helicobacter Pylori Isolates from Chaharmahal and Bakhtiari Province, Iran. J Isfahan Med Sch. 2012;30(197). https://www. researchgate.net/publication/233902441.

45. Sedaghat H, Moniri R, Jamali R, Arj A, Zadeh MR, Moosavi SGA, et al. Prevalence of helicobacter pylori vacA, cagA, cagE, iceA, babA2, and oipA genotypes in patients with upper gastrointestinal diseases. Iran J Microbiol. 2014;6(1):14.

46. Rafeey M, Ghotaslou R, Milani M, Farokhi N, Ghojazadeh M. Association between helicobacter pylori, cagA, and vacA status and clinical presentation in Iranian children. Iran J Pediatr. 2013;23(5):551.

47. Souod N, Kargar M, Doosti A, Ranjbar R, Sarshar M. Genetic analysis of cagA and vacA genes in helicobacter pylori isolates and their relationship with gastroduodenal diseases in the west of Iran. Iran Red Crescent Med J. 2013; 15(5):371.
48. Pajavand H, Alvandi A, Mohajeri P, Bakhtyari S, Bashiri H, Kalali B, et al. High frequency of vacA s1m2 genotypes among Helicobacter pylori isolates from patients with gastroduodenal disorders in Kermanshah, Iran. Jundishapur J Microbiol. 2015;8(11):e25425.

49. Jafari F, Shokrzadeh L, Dabiri H, Baghaei K, Yamaoka Y, Zojaji H, et al. vacA genotypes of Helicobacter pylori in relation to cagA status and clinical outcomes in Iranian populations. Japan J Infect Dis. 2008;61(4):290.

50. Mohammadi M, Oghalaie A, Mohajerani N, Massarrat S, Nasiri M, Bennedsen $M$, et al. Prevalence of Helicobacter pylori vacuolating cytotoxin and its allelic mosaicism as a predictive marker for Iranian dyspeptic patients. Bull Soc Pathol Exot (1990). 2003;96(1):3-5.

51. Falsafi T, Khani A, Mahjoub F, Asgarani E, Sotoudeh N. Analysis of vacA/cagA genotypes/status in helicobacter pylori isolates from Iranian children and their association with clinical outcome. Turkish J Med Sci. 2015;45(1):170-7.

52. Kamali-Sarvestani E, Bazargani A, Masoudian M, Lankarani K, Taghavi A-R, Saberifiroozi M. Association of $\mathrm{H}$ pylori cagA and vacA genotypes and IL-8 gene polymorphisms with clinical outcome of infection in Iranian patients with gastrointestinal diseases. World J Gastroenterol: WJG. 2006;12(32):5205.

53. Miftahussurur M, Yamaoka Y. Helicobacter pylori virulence genes and host genetic polymorphisms as risk factors for peptic ulcer disease. Expert Rev Gastroenterol Hepatol. 2015;9(12):1535-47.

54. Zamani M, Ebrahimtabar F, Zamani V, Miller W, Alizadeh-Navaei R, ShokriShirvani J, et al. Systematic review with meta-analysis: the worldwide prevalence of helicobacter pylori infection. Aliment Pharmacol Ther. 2018; 47(7):868-76.

55. Massarrat S, Saberi-Firoozi M, Soleimani A, Himmelmann GW, Hitzges M, Keshavarz H. Peptic ulcer disease, irritable bowel syndrome and constipation in two populations in Iran. Eur J Gastroenterol Hepatol. 1995; 7(5):427-33.

56. Akhter Y, Ahmed I, Devi SM, Ahmed N. The co-evolved helicobacter pylori and gastric cancer: trinity of bacterial virulence, host susceptibility and lifestyle. Infect Agents Cancer. 2007;2(1):2.

57. Singh K, Ghoshal UC. Causal role of helicobacter pylori infection in gastric cancer: an Asian enigma. World J Gastroenterol: WJG. 2006;12(9):1346.

58. Duck WM, Sobel J, Pruckler JM, Song Q, Swerdlow D, Friedman C, et al. Antimicrobial resistance incidence and risk factors among helicobacter pylori-infected persons, United States. Emerg Infect Dis. 2004;10(6):1088.

59. Vale F, Vitor J. Transmission pathway of helicobacter pylori: does food play a role in rural and urban areas? Int J Food Microbiol. 2010;138(1-2):1-12.

60. Safak B, Ciftci IH, Dilek FH, Uslan I, Cetinkaya Z, Asik G, et al. Prevalence of cag a and vac a genotypes of helicobacter pylori isolated from Turkish patients with active or non-active chronic gastritis. Scand I Infect Dis. 2010; 42(6-7):435-8.

61. Lee A, Fox J, Hazell S. Pathogenicity of helicobacter pylori: a perspective. Infect Immun. 1993;61(5):1601.

62. Liu J, He C, Chen M, Wang Z, Xing C, Yuan Y. Association of presence/ absence and on/off patterns of helicobacter pylori oipA gene with peptic ulcer disease and gastric cancer risks: a meta-analysis. BMC Infect Dis. 2013; 13(1):555.

63. Chen M-Y, He C-Y, Meng X, Yuan Y. Association of helicobacter pylori babA2 with peptic ulcer disease and gastric cancer. World J Gastroenterol: WJG. 2013;19(26):4242.

64. Hussein $\mathrm{N}$. The association of dupA and helicobacter pylori-related gastroduodenal diseases. Eur J Clin Microbiol Infect Dis. 2010;29(7):817-21.

65. Shiota S, Watada M, Matsunari O, Iwatani S, Suzuki R, Yamaoka Y. Helicobacter pylori iceA, clinical outcomes, and correlation with cagA: a meta-analysis. PLoS One. 2012;7(1):e30354.

66. Sahara S, Sugimoto M, Vilaichone R-K, Mahachai V, Miyajima H, Furuta T, et al. Role of helicobacter pyloricagA EPIYA motif and vacAgenotypes for the development of gastrointestinal diseases in southeast Asian countries: a meta-analysis. BMC Infect Dis. 2012;12(1):223.

67. Matsunari O, Shiota S, Suzuki R, Watada M, Kinjo N, Murakami K, et al. Association between helicobacter pylori virulence factors and gastroduodenal diseases in Okinawa, Japan. J Clin Microbiol. 2012;50(3):876-83.

68. Yordanov D, Boyanova L, Markovska R, Gergova G, Mitov I. Significance of helicobacter pylori vacA intermediate region genotyping - a Bulgarian study. Diagn Microbiol Infect Dis. 2012;74(3):253-7.

69. Meining A, Kiel G, Stolte M. Changes in helicobacter pylori-induced gastritis in the antrum and corpus during and after 12 months of treatment with ranitidine and lansoprazole in patients with duodenal ulcer disease. Aliment Pharmacol Ther. 1998;12(8):735-40. 
70. Fahimi F, Tohidkia MR, Fouladi M, Aghabeygi R, Samadi N, Omidi Y. Pleiotropic cytotoxicity of VacA toxin in host cells and its impact on immunotherapy. Biolmpacts. 2017;7(1):59.

71. Boquet P, Ricci V, Galmiche A, Gauthier NC. Gastric cell apoptosis and H. pylori: has the main function of VacA finally been identified? Trends Microbiol. 2003;11(9):410-3.

72. Arents NL, Van Zwet AA, Thijs JC, Kooistra-Smid AM, Van Slochteren KR, Degener JE, et al. The importance of vacA, cagA, and iceA genotypes of helicobacter pylori infection in peptic ulcer disease and gastroesophageal reflux disease. Am J Gastroenterol. 2001;96(9):2603-8.

73. Talebkhan Y, Mohammadi M. Vacuolating cytotoxin of helicobacter pylori. Iran J Biotechnol. 2003;1(2):73-81.

74. McClain MS, Cao P, Iwamoto H, Vinion-Dubiel AD, Szabo G, Shao Z, et al. A 12-amino-acid segment, present in type s2 but not type s1 helicobacter pylori VacA proteins, abolishes cytotoxin activity and alters membrane channel formation. J Bacteriol. 2001;183(22):6499-508.

75. Atherton JC, Cao P, Peek RM, Tummuru MK, Blaser MJ, Cover TL. Mosaicism in vacuolating cytotoxin alleles of helicobacter pylori association of specific vacA types with cytotoxin production and peptic ulceration. J Biol Chem. 1995;270(30):17771-7.

76. Strobel S, Bereswill S, Balig P, Allgaier P, Sonntag H-G, Kist M. Identification and analysis of a NewvacA genotype variant of helicobacter pylori in different patient groups in Germany. J Clin Microbiol. 1998;36(5):1285-9.

77. El-Shenawy A, Diab M, Shemis M, El-Ghannam M, Salem D, Abdelnasser M, et al. Detection of helicobacter pylori vacA, cagA and iceA1 virulence genes associated with gastric diseases in Egyptian patients. Egyptian J Med Hum Genet. 2017;18(4):365-71

78. Pinto-Ribeiro I, Ferreira RM, Batalha S, Hlaing T, Wong SI, Carneiro F, et al. Helicobacter pylori vacA genotypes in chronic gastritis and gastric carcinoma patients from Macau, China. Toxins. 2016;8(5):142.

79. Martins LC, TCdO C, Demachki S, Araujo MT, Assumpção MB, SCAJ V, et al. Clinical and pathological importance of vacA allele heterogeneity and cagA status in peptic ulcer disease in patients from North Brazil. Mem Inst Oswaldo Cruz. 2005;100(8):875-81.

80. Sugimoto M, Yamaoka Y. The association of vacA genotype and helicobacter pylori-related disease in Latin American and African populations. Clin Microbiol Infect. 2009;15(9):835-42.

81. Li Q, Liu J, Gong Y, Yuan Y. Association of CagA EPIYA-D or EPIYA-C phosphorylation sites with peptic ulcer and gastric cancer risks: A metaanalysis. Medicine. 2017;96(17):e6620. https://doi.org/10.1097/MD. 0000000000006620.

82. Basiri Z, Safaralizadeh R, Bonyadi MJ, Somi MH, Mahdavi M, Latifi-Navid S. Helicobacter pylori vacA d1 genotype predicts risk of gastric adenocarcinoma and peptic ulcers in northwestern Iran. Asian Pac J Cancer Prev. 2014;15(4):1575-9.

83. Mottaghi B, Safaralizadeh R, Bonyadi M, Latifi-Navid S, Somi MH. Helicobacter pylori vacA i region polymorphism but not babA2 status associated to gastric cancer risk in northwestern Iran. Clin Exp Med. 2016; 16(1):57-63.

84. Yamaoka Y, Orito E, Mizokami M, Gutierrez O, Saitou N, Kodama T, et al. Helicobacter pylori in north and south america before Columbus. FEBS Lett. 2002;517(1-3):180-4.

85. Miehlke S, Kirsch C, Agha-Amiri K, Günther T, Lehn N, Malfertheiner P, et al, The helicobacter pylori vacA s1, m1 genotype and cagA is associated with gastric carcinoma in Germany. Int J Cancer. 2000;87(3):322-7.

86. Yamaoka Y, Kodama T, Gutierrez O, Kim JG, Kashima K, Graham DY. Relationship between helicobacter pylori iceA, cagA, and vacA status and clinical outcome: studies in four different countries. J Clin Microbiol. 1999; 37(7):2274-9.

87. Van Doorn LJ, Figueiredo C, Mégraud F, Pena S, Midolo P, Queiroz DMDM, et al. Geographic distribution of vacA allelic types of helicobacter pylori. Gastroenterology. 1999;116(4):823-30.

88. Latifi-Navid S, Ghorashi SA, Siavoshi F, Linz B, Massarrat S, Khegay T, et al. Ethnic and geographic differentiation of helicobacter pylori within Iran. PLoS One. 2010;5(3):e9645.

89. Zhang B-B, Li Y, Liu X-Q, Wang P-J, Yang B, Bian D-L. Association between vacA genotypes and the risk of duodenal ulcer: a meta-analysis. Mol Biol Rep. 2014;41(11):7241-54.

90. Román-Román A, Martínez-Carrillo DN, Atrisco-Morales J, Azúcar-Heziquio JC, Cuevas-Caballero AS, Castañón-Sánchez CA, et al. Helicobacter pylori vacA s1m1 genotype but not cagA or babA2 increase the risk of ulcer and gastric cancer in patients from southern Mexico. Gut Pathogens. 2017;9(1): 18.

91. Sugimoto M, Zali M, Yamaoka Y. The association of vacA genotypes and helicobacter pylori-related gastroduodenal diseases in the Middle East. Eur Clin Microbiol Infect Dis. 2009;28(10):1227-36.

92. Chambers MG, Pyburn TM, González-Rivera C, Collier SE, Eli I, Yip CK, et al. Structural analysis of the oligomeric states of helicobacter pylori VacA toxin. J Mol Biol. 2013;425(3):524-35.

93. Letley D, Lastovica A, Louw J, Hawkey C, Atherton J. Allelic diversity of the helicobacter pylori Vacuolating Cytotoxin gene in South Africa: rarity of thevacA s1a genotype and natural occurrence of an s2/m1 allele. J Clin Microbiol. 1999;37(4):1203-5.

\section{Publisher's Note}

Springer Nature remains neutral with regard to jurisdictional claims in published maps and institutional affiliations.
Ready to submit your research? Choose BMC and benefit from:

- fast, convenient online submission

- thorough peer review by experienced researchers in your field

- rapid publication on acceptance

- support for research data, including large and complex data types

- gold Open Access which fosters wider collaboration and increased citations

- maximum visibility for your research: over $100 \mathrm{M}$ website views per year

At BMC, research is always in progress.

Learn more biomedcentral.com/submissions 